Original article

\title{
İlkokullarda Görev Yapan Öğretmenlerin Çevreye Yönelik Tutumlarının Sosyodemografik Özellikler Açısından Değerlendirilmesi: Düzce İli Örneği
}

\section{Abstract Evoluation of the Attitudes of Teachers Working in Primary Schools towards the Environment in Terms of Sociodemographic Characteristics, Example of Düzce Province}

\author{
Mehtap Kılıç (D) a, * \& Alptürk Akçöltekin (D) b \\ a Department of Disaster Management, Dokuz Eylül University, İzmir, Turkey \\ ${ }^{b}$ Department of Physical Education and Sports Teaching, Ardahan University, Ardahan, Turkey
}

\begin{abstract}
Özet
Çevre tüm varlıkların içerisinde etkileşimde bulunduğu ve geleceğin şekillendiği yaşam alanıdır. Bu yaşam alanının gelecek nesillere güvenle aktarılması, canlı hayatının sürekliliğini sağlayacaktır. Sürdürülebilir bir çevre, bizden sonraki nesillere aktarmamız gereken en değerli mirastır. Sürdürülebilir bir çevrenin sağlanması için ileride her biri geleceğimizi şekillendirecek bireyler olmaya aday olan çocukların, çevre konusunda iyi eğitilmesi gerekmektedir. İlkokul öğretmenleri bu noktada, küçük yaşlarda aşılanması gereken çevre koruyucu tavır ve tutumları öğrencilere kazandırmakta kilit rol oynamaktadır. Gelecek nesillerimizin bilinçli ve çevreye karşı daha duyarlı olması için ilkokul öğretmenlerine büyük sorumluluklar düşmektedir. Bu çalışmada ilkokul öğretmenlerinin çevreye yönelik tutumları ele alınmış ve bu çerçevede insanların çevreye bakış açıları, çevre hakkında sahip oldukları bilgi birikimi, çevresel sorunlarının farkında olma durumları ve çevre sorunlarıyla karşılaştıklarında bu sorunlarla baş edebilme kapasitelerini ortaya koymak amaçlanmaktadır. Araştırmada katılımcıların beceri, ilgi, yetenek, tutum gibi özelliklerini tespit etmede tercih edilen nicel araştırma yöntemlerinden birisi olan tarama modeli kullanılmıştır. Verilerin toplanmasında dört alt boyuttan oluşan Çevresel Tutum Ölçeği (ÇTÖ), verilerin analizinde ise SPSS (Statistical Package for the Social Sciences) programı kullanılmıştır. Araştırmadan elde edilen sonuçlara göre öğretmenlerin cinsiyetleri ile çevresel tutumları arasında anlamlı ilişkiye rastlanmıştır. Kadın öğretmenlerin erkek öğretmenlere göre çevresel tutumlarının daha olumlu yönde olduğu, bu doğrultuda da erkek öğretmenlere yönelik çevresel tutumların iyileştirilmesi gerektiği sonucuna ulaşılmıştır.
\end{abstract}

Anahtar Kelimeler: Çevre, Çevre Eğitimi, Çevresel Tutum, Sürdürülebilir Çevre.

\begin{abstract}
Environment is the living space where all beings interact and the future is shaped. The transfer of this living space to future generations will ensure the continuity of its live life. A sustainable environment is the most valuable heritage that we must pass on to the next generations. In order to provide a sustainable environment, children who are candidates to become individuals who will shape our future in the future should be well educated about the environment. Primary school teachers play a key role in gaining environmentally protective attitudes and attitudes that need to be teached at young ages. Primary school teachers have
\end{abstract}

\footnotetext{
* Corresponding author:

Mehtap Kılıç, Department of Disaster Management, Dokuz Eylül University, İzmir, Turkey. Email: mhtpklc8181@gmail.com
} 
great responsibilities for our future generations to be conscious and more sensitive to the environment. In this study, primary school teachers' attitudes towards the environment have been discussed and within this framework, it is aimed to reveal the people's perspective to the environment, their knowledge of the environment, their awareness of environmental problems and their capacity to cope with environmental problems when they encounter environmental problems. In the research, scanning model, which is one of the preferred quantitative research methods, was used to determine the characteristics of the participants such as skills, interests, abilities, and attitudes. The Environmental Attitude Scale (EAS) consisting of four sub-dimensions was used to collect the data and the SPSS (Statistical Package for the Social Sciences) program was used for the analysis of the data. According to the results obtained from the study, a significant differences was found between the gender of teachers and their environmental attitudes. It was concluded that the environmental attitudes of female teachers were more positive than male teachers, and accordingly, environmental attitudes towards male teachers should be improved.

Keywords: Environment, Environmental Education, Environmental Attitude, Sustainable Environment.

Received: 01 September $2020 \quad * \quad$ Accepted: 01 December $2020 \quad * \quad$ DOI: https://doi.org/10.29329/jpee.2020.282.2

\section{Gíriș}

Çevre içerisinde canlı ve cansız varlıkların bir arada bulunduğu, insan hayatının devamlılı̆g 1 için büyük öneme sahip olan yaşam alanıdır. Çevre aynı zamanda karşılıklı faydanın sağlandığı, doğa insan uyumunun denge halinde sürdürülmesi gereken bir ortam olarak karşımıza çıkmaktadır.

İnsanoğlu ilk olarak doğadan yararlanma amacıyla doğayı kullanmaya başlamış, daha sonra bilime olan katkıların da artmasıyla doğaya egemen olma anlayışına bürünmüş ve bu anlayış zamanla sömürgeciliğe dönüşmüştür (Türküm, 1998). Bu sömürgecilik yarışı dünyadaki kaynakların zamanla tükenmesine ve varlığını sürdürebilmesi için elinde bulundurduğu potansiyel var olma süresinin zamanla daha da kısalmasına yol açmıştır.

Ülkeler gelişebilme açısından birbirleriyle yarış içerisine girmişlerdir. Bu yarıştan dünyanın etkilenmemesi söz konusu değildir. Dünyanın herhangi bir yerinde yapılacak olan olumsuz bir davranışın diğer bölgeleri etkilememesi neredeyse imkansızdır. Çevreye verilen zarar yalnızca zarar verilen ortamla sınırlı kalmayıp etrafındaki coğrafyayı da geniş ölçüde etkilemektedir. Çevreyi olumsuz yönde etkileyecek şekilde yapılan herhangi bir davranış çevrenin geri dönülmez şekilde tahribatına yol açabilmektedir. Tüm bu nedenlerden dolayı çevreye verilen zararın önlenmesi ve gelecek nesillere daha sürdürülebilir bir yaşam bırakmak adına çeşitli çevre politikaları ortaya çıkmıştır.

Alım (2006)' ya göre çevre politikası; çevre sorunlarının çözümü için geleceğe yönelik olarak alınması gereken tedbirlerin ve benimsenen ilkelerin bütününü oluşturur. Alınacak bu tedbirler arasında en önemlilerinden birisi de şüphesiz çevreye yönelik eğitimler verilmesidir. Çevreye karşı daha hassas bireyler yetiştirmek, gelecek nesilleri de çevreyi nasıl sürdürülebilir hale getireceği konusunda bilinçlendirmek çevreye yönelik alınabilecek en etkili yöntemlerdendir. 
Çevre eğitimi kavramı 1960'larda ortaya çıkmış ve 1970'lerin sonunda bu kavrama çeşitli eklemeler yapılmıştır (Jickling ve Spork, 1998). Çevre eğitimi; toplumu çevre hakkında bilgilendirerek bu konuda bilinçlenmelerini sağlamak ve insanlarda kalıcı davranış değişikliği oluşturmak amacıyla tüm bireylere verilmesi sağlanmalıdır. Çevre eğitiminin temel amacı; eğitim alan tüm bireylerin bu süreç sonrasında çevreye karşı daha hassas olmalarını, sorumlu davranışlar sergilemelerini ve çevre hakkında değer yargıları olan donanımlı bireyler olarak yetişmelerini sağlamaktır (Çabuk ve Karacaoğlu, 2003). Çevre eğitiminin daha faydalı olabilmesi için ise öncelikle; çeşitli öğretim yöntem ve tekniklerini kullanarak öğrencilere katkı sağlayan, onların bakış açılarını değiştirerek faydalı davranışlar sergilemesini sağlayan öğretmenlerimizin çevre konusunda daha fazla bilinçlenmesi gerekmektedir (Keleş, Uzun ve Varnacı Uzun, 2010). Kahyaoğlu ve Özgen (2012) 'e göre çevreye olan hassasiyeti yüksek, çevre hakkında yeterli bilgiye sahip, çevre çalışmalarını her anlamda başarıyla gerçekleştirebilecek donanıma sahip öğretmenlerin yetiştirilmesi çevre eğitimlerinin amacına ulaştırılmasında oldukça önemlidir.

Birçok bilim insanı çevre sorunlarına neden olan unsurları araştırmış ve bunları önleme üzerine çalışmalar yapmıştır. Costanza (1991)' e göre ekosistem denilen bu yapı doğal ve insan eseri birçok unsur içerir ve çevre sorunlarına insan eseri olan (araçlar, silahlar, yapılar, şehirler, yollar, otomobiller, uçaklar) birçok unsur sebep olur. Bu unsurlar zamanla şüphesiz doğal nüfusu da giderek azaltır veya tamamen tüketir. Çevre, insan hayatının devamlılığını sağlamak için gerekliyken; çevre sorunlarının yaşanması, çevrenin kendini onarabilmesi ve canlı yaşamın devamlılı̆̆ı açısından tehdit oluşturmaktadır (Kaypak, 2013).

Son zamanlarda çevre sorunlarının çözülmesi üzerinde birçok çalışma yapılmakta ve çözüm önerileri sunulmaktadır. Baykal ve Baykal (2008)'e göre 20. yüzyılda etkisi hissedilmeye başlanan ve 21. yüzyılda da hızla devam eden çevre sorunları insanlar için önlem alma gerekliliğini ortaya çıkarmış ve bireyleri önlem almaya, yetkilileri de çevre hakkında çeşitli antlaşmalar yapmaya yöneltmiştir.

Avrupa Birliği başta olmak üzere birçok kurum ve kuruluş çevre sorunları hakkında çözüm üretmeye çalışmış ve çeşitli projeler ortaya koymuşlardır. Yapılan çalışmalarda gereken bütçenin oldukça fazla olmasının yanında, projelerin başarıya ulaşması için her bireye de çevreye karşı yerine getirmesi gereken çeşitli sorumluluklar düşmektedir. Bunun için öncelikle toplumda küçük yaşlardan itibaren çevre bilincinin oluşturulması gerekmektedir. Bireyler üzerine düşen sorumlulukları bilmeli ve buna göre davranış değişikliği oluşturmalıdır. Bu da ancak küçük yaşlardan itibaren çevre hakkında eğitimler verilerek sağlanabilir (Alım, 2006). Eğitim, bireyin farkında olarak davranışlarında bilerek ve isteyerek değişiklikler oluşturması sürecidir. Bireyler davranış değişikliği yaşarken aynı zamanda da onları bekleyen hayata kendilerini eğitim sayesinde hazırlamaktadır. Eğitim her alanda olduğu gibi çevre sorunlarının önüne geçilmesinde de önemli rol oynamaktadır. İnsanı insan yapan her türlü bilgi, beceri ve tutumlar, ona eğitim yoluyla kazandırılır (Çelikkıran, 1995). Eğitim denildiğinde ise tabi ki akla ilk 
olarak bu alanda uzman olan öğretmenler gelmektedir. Gelecek nesillerin çevreye daha duyarlı olabilmeleri için küçük yaşlarda verilmesi gereken bu eğitim de tabi ki büyük ölçüde ilköğretim öğretmenleri sayesinde olacaktır.

\section{Araştırmanın Önemi}

Çevre, içinde bulunduğumuz dünyanın sürdürülebilirliğini sağlamada oldukça önemli bir yere sahiptir. Dünyanın gelecek nesillere iyi koşullar sağlaması için çevremizin her anlamda korunması gerekmektedir.

Farkındalığı sağlamanın en önemli yollarından biri insanları çevre hakkında bilinçlendirmektir. $\mathrm{Bu}$ da çevre eğitimlerinin üzerinde durularak gerçekleştirilebilir. Eğitimin küçük yaşlarda verilmesi bu bilincin önceden aşılanması ve kalıcı olması adına çok önemlidir. Bu bağlamda ilkokul öğretmenlerinin üzerine büyük sorumluluklar düşmektedir.

\section{Araştırmanın Amacı}

$\mathrm{Bu}$ araştırmanın amacı, ilkokul öğretmenlerinin çevresel tutumları ile sosyodemografik değişkenleri (branş, cinsiyet, yaş, medeni durum, mesleki kıdem ve aylık gelir) arasındaki ilişkiyi ortaya çıkarmaktır.

\section{Alt Problemler}

$\mathrm{Bu}$ araştırma ile ilkokullarda görev yapan öğretmenlerinin (sınıf öğretmeni, İngilizce, Türkçe, okul öncesi, diğer) çevresel tutumları sosyodemografik değişkenler açısından incelenmiştir. İlkokul öğretmenlerinin çevreye yönelik tutumlarının sosyodemografik değişkenlere göre nasıl değiştiğini belirlemek için aşağıdaki sorulara yanıtlar aranmıştır.

1. İlkokul öğretmenlerinin çevreye yönelik genel tutumları ile ölçeğin faktörlerine yönelik tutumları hangi düzeydedir?

2. Öğretmenlerin çevreye yönelik genel tutumları ve ölçeğin faktörleri ile cinsiyet değişkeni arasında istatistiki açıdan anlamlı fark var mıdır?

3. Öğretmenlerin çevreye yönelik genel tutumları ve ölçeğin faktörleri ile yaş değişkeni arasında istatistiki açıdan anlamlı farklılık var mıdır?

4. Öğretmenlerin çevreye yönelik genel tutumları ve ölçeğin faktörleri ile medeni durum değişkeni arasında istatistiki açıdan anlamlı farklılık var mıdır?

5. Öğretmenlerin çevreye yönelik genel tutumları ve ölçeğin faktörleri ile mesleki kıdem değişkeni arasında istatistiki açıdan anlamlı farklılık var mıdır?

6. Öğretmenlerin çevreye yönelik genel tutumları ve ölçeğin faktörleri ile aylık gelir değişkeni arasında istatistiki açıdan anlamlı farklılık var mıdır? 
7. Öğretmenlerin çevreye yönelik genel tutumları ve ölçeğin faktörleri ile branş değişkeni arasında istatistiki açıdan anlamlı farklılık var mıdır?

\section{YÖNTEM}

\section{Araştırmanın Modeli}

$\mathrm{Bu}$ çalışmada, katılımcıların görüşlerini ya da beceri, ilgi, yetenek, tutum gibi özelliklerini tespit etmede tercih edilen nicel araştırma yöntemlerinden birisi olan tarama modeli kullanılmıştır.

\section{Evren ve Örneklem}

Evren, araştırma sonuçlarının genellenmek istendiği elemanlar bütünüdür. Bu bütün, ortak özellikleri olan canlı ya da cansı her türlü elemanı içerebilir (Asan, 2015). Örneklem, evreni temsil etmek üzere çeşitli tekniklerle evren elemanlarından seçilen ve üzerinde inceleme yapılan gruptur. Örnekleme ise, bir süreç olup bir çalışmada evreni temsil edecek bireylerin belirlenmesidir. Seçilmiş bireyler bir örneklerinin içinde yer alarak bir evrendeki büyük grupları temsil ederler (Özen ve Gül, 2007). Araştırmanın örneklem seçiminde basit rastgele örnekleme yöntemi kullanılmıştır. Basit rasgele örnekleme yönteminde, evrenden seçilecek olan her örneklem eşit derecede seçilme şansına sahiptir (Karakülah, 2006).

Araştırmanın evrenini 2019-2020 eğitim öğretim yılı içerisinde Düzce ilinde çalışan ilkokul öğretmenleri, örneklemini de Düzce ili içerisinde araştırma izni verilen 30 ilkokuldan seçilen ilkokul öğretmeleri oluşturmaktadır. Bu evrendeki 188 öğretmen araştırmanın örneklemini oluşturmuştur. Tablo 1'de katılımcıların demografik özellikleri ile birlikte frekans ve yüzdeleri verilmiştir. 
Tablo 1. Katılımcıların Demografik Özellikleri

\begin{tabular}{|c|c|c|c|}
\hline Değişken & Gruplar & Frekans $(\mathbf{F})$ & Yüzde (\%) \\
\hline \multirow[t]{2}{*}{ Cinsiyet } & Kadın & 131 & 69.7 \\
\hline & Erkek & 57 & 30.3 \\
\hline \multirow[t]{2}{*}{ Medeni Durum } & Evli & 145 & 77.1 \\
\hline & Bekar & 43 & 22.9 \\
\hline \multirow[t]{5}{*}{ Yaş } & $18-25$ yaş & 15 & 8.0 \\
\hline & $26-35$ yaş & 65 & 34.6 \\
\hline & $36-45$ yaş & 74 & 39.4 \\
\hline & 46-54 yaş & 26 & 13.8 \\
\hline & 55 yaş ve üzeri & 8 & 4.3 \\
\hline \multirow[t]{5}{*}{ Branş } & Sınıf Öğretmeni & 129 & 68.6 \\
\hline & İngilizce Öğretmeni & 13 & 6.9 \\
\hline & Türkçe Öğretmeni & 11 & 5.9 \\
\hline & Okul Öncesi Öğretmeni & 9 & 4.8 \\
\hline & Diğer & 26 & 13.8 \\
\hline \multirow[t]{4}{*}{ Aylık Gelir } & $1000-2499 \mathrm{TL}$ & 12 & 6.4 \\
\hline & $2500-3499 \mathrm{TL}$ & 5 & 2.7 \\
\hline & 3500- $4499 \mathrm{TL}$ & 80 & 42.6 \\
\hline & 4500 TL ve üzeri & 91 & 48.4 \\
\hline \multirow[t]{4}{*}{ Kıdem } & $1-10$ yil & 72 & 38.3 \\
\hline & $11-20$ y1l & 68 & 36.2 \\
\hline & 21-29 y1l & 31 & 16.5 \\
\hline & 30 yıl ve üzeri & 17 & 9.0 \\
\hline
\end{tabular}

Tablo 1'e göre katılanların \% 69.7'si kadın iken \% 30.3'ü erkektir. Medeni durumlarına göre katılımcıların \% 77.1'i evli \% 22.9'u bekardır yani çoğunluk evli gruptan oluşmaktadır. Katılımcılar yaşlarına göre en az \% 8 ile 18-25 yaş aralığından, en fazla ise \% 39.4 ile 36-45 yaş aralığından oluşmaktadır. Katılımcılar branş bazında en fazla \% 68.9 ile sınıf öğretmenlerinden oluşmakta, en az ise \% 4.8 ile okul öncesi öğretmenlerinden oluşmaktadır. Aylık gelirlere bakıldığında, katılımcıların \% 48.4'lük kısmı 4500 TL ve üzeri maaş alırken \% 6.4'lük bir kısmı da 1000- 2499 TL arasında maaş almaktadırlar. Mesleki kıdeme göre bakıldığında katılımcılar \%38.3 ile en fazla 1-10 yıl arası çalışan öğretmenlerden oluşurken en az ise \%9 ile 30 yıl ve üzeri çalışan öğretmenlerden oluşmaktadır.

\section{Verilerin Toplanması}

Araştırmada kullanılacak olan ölçeğin öğretmenler üzerinde uygulanabilmesi için Düzce İl Milli Eğitim Bakanlığına resmi olarak izin talebinde bulunulmuştur. Talep doğrultusunda cevap olumlu olmuş ve izin sonucu ekte gösterilmiştir. 
Araştırmada kullanılacak olan veriler Kasım - Aralık ayları arasında, izin doğrultusunda Düzce ilindeki 30 ilkokulda görev yapan 188 öğretmenden anket yoluyla toplanmıştır. Anketler yüz yüze görüşülerek toplandığından araştırmada veri kaybı olmamıştır.

\section{Veri Toplama Araçları}

Araştırmada veri toplama aracı olarak öğretmenlerin çevreye yönelik tutumunu ölçmek amacıyla Tuncer, Ertepınar, Tekkaya ve Sungur (2005) tarafindan geliştirilen Çevresel Tutum Ölçeği (ÇTÖ) kullanılmıştır. Bu ölçek toplamda 45 maddeden oluşmakta ve her madde 4 farklı alt boyut ölçmektedir. Araştırmada bu ölçeğin seçilmiş olmasının nedeni çevresel tutumların farklı boyutlarını ele almış olmasidir.

\section{Çevresel Tutum Ölçeği}

Araştırmada Tuncer, Ertepınar, Tekkaya ve Sungur (2005) tarafından geliştirilen Çevresel Tutum Ölçeği (ÇTÖ) kullanılmıştır. Ölçek toplamda 45 sorudan oluşan dört alt boyuttan oluşur. Bu alt boyutlar 12 maddeden oluşan çevre sorunları farkındalığı, 15 maddeden oluşan çözüme yönelik tutumlar, 13 maddeden oluşan bireysel sorumluluk bilinci ve 6 sorudan oluşan ulusal çevre problemleri farkındalığıdır.

Ölçeğin puanlama işleminde maddeler; kesinlikle katılmıyorum $=1$, katılmıorum $=2$, kararsızım $=3$, katılıyorum $=4$, kesinlikle katılıyorum $=5$, bilmiyorum $=6$ şeklinde numaralandırılmıştır.

\section{BULGULAR}

Araştırmanın bu bölümünde, katılımcılardan çevresel tutum ölçeği aracıllığı ile toplanan verilerin analiz edilmesi sonucunda araştırmanın alt problemlerine ilişkin bulgularına yer verilmiştir. Alt problemlere ilişkin elde edilen bulgular tablo haline getirilip yorumlarıly birlikte verilmiştir.

\section{Araştırmanın Birinci Alt Problemine İlişkin Bulgular}

Öğretmenlerin çevresel tutum ölçeğine vermiş olduğu cevapların betimsel analiz sonuçları tablo 2'de verilmiştir. 
Tablo 2. Çevresel Tutum Ölçeği ve Alt Boyutlarına Ait Betimleyici İstatistikler

\begin{tabular}{lccccc}
\hline & $\mathbf{N}$ & Min & Max & M & SS \\
\hline ÇSF & 188 & 1.75 & 4.25 & 3.00 & 0.37 \\
ÇYT & 188 & 2.27 & 4.67 & 3.48 & 0.36 \\
BSB & 188 & 2.38 & 4.77 & 3.95 & 0.37 \\
UÇF & 188 & 2.00 & 4.33 & 3.07 & 0.37 \\
\hline Toplam & 188 & 8.40 & 18.02 & 13.50 & 1.47 \\
\hline
\end{tabular}

Tablo 2 incelendiğinde ölçekten elde edilen toplam puan ortalamas $\bar{x}=13.50$ ve standart sapması 1.47 'dir. Bu bulguya göre ilkokul öğretmenlerinin çevreye yönelik tutumlarının yüksek olduğu belirlenmiştir. Ayrıca öğretmenlerin ölçeğin alt boyutlarından aldıkları toplam ortalama puanlarının da yüksek olduğu görülmektedir.

Öğretmenlerin Çevresel Tutum Ölçeği’ ne verdikleri cevaplardan elde edilen bulgulara göre sonuçlar tablo haline getirilmiş ve ölçekteki tüm maddelerin aritmetik ortalamaları $(\bar{x})$ ve standart sapmaları (SS) Tablo 3’te verilmiştir.

Tablo 3. Çevresel Tutum Ölçeği İfadeleri

\begin{tabular}{lccc}
\hline Boyutlar & Toplam Madde Sayısı & $\overline{\mathbf{x}}$ & Ss \\
\hline ÇSF madde ortalaması & 12 & 3.00 & 1.08 \\
ÇYT madde ortalaması & 15 & 3.48 & 1.14 \\
BSB madde ortalaması & 13 & 3.94 & 0.97 \\
UÇF madde ortalaması & 6 & 3.06 & 0.90 \\
\hline
\end{tabular}

Tablo 3'te çevresel tutum ölçeği alt boyutlarının ortalamaları verilmiştir. Çevre sorunları farkındalığı madde ortalaması $\overline{\mathrm{X}}=3.00$ olarak, çözüme yönelik tutum madde ortalaması $\overline{\mathrm{x}}=3.48$ olarak, bireysel sorumluluk bilinci madde ortalaması $\overline{\mathrm{x}}=3.94$ olarak, ulusal çevre farkındalığı madde ortalaması ise $\bar{x}=3.06$ olarak bulunmuştur.

Çevre sorunları farkındalığı alt problemine ilişkin en yüksek ortalamaya sahip ifade "Çevre kirliliği insan sağlığını olumsuz yönde etkiler" şeklindeki 35. ifadedir ( $\bar{x}=4.71)$. En düşük ortalamaya sahip ifade ise "Denizlerin içinde yüzülemeyecek kadar kirli hale gelmesi doğal bir olaydır" şeklindeki 6. ifadedir $(\bar{x}=1.57)$.

Çözüme yönelik tutum alt problemine ilişkin en yüksek ortalamaya sahip ifade "İnsanoğlu yaşamını sürdürebilmek için doğa ile uyum içinde yaşamak zorundadır" ş̧eklindeki 2. ifadedir ( $\overline{\mathrm{x}}=4.78$ ). En düşük ortalamaya sahip ifade ise "Çevre kirliliğinin nüfus artışı ile hiçbir ilgisi yoktur" şeklindeki 34. ifadedir $(\bar{x}=1.61)$. 
Bireysel sorumluluk bilinci alt problemine ilişkin en yüksek ortalamaya sahip ifade "Çevre kirliliğinin önlenmesinde bireylerin sorumlulukları çok önemlidir" ve "Su ve elektrik kullanırken tasarruflu davranmak, doğal kaynakların sürdürülebilir kullanımı açısından önemlidir" şeklindeki 24. ve 44. ifadelerdir $(\bar{x}=4.70)$. En düşük ortalamaya sahip ifade ise "Tüketim alışkanlıklarımızın doğal kaynakların tükenmesi ile ilgisi yoktur” şeklindeki 41. ifadedir ( $\bar{x}=1.77)$.

Ulusal çevre farkındalığı alt problemine ilişkin en yüksek ortalamaya sahip ifade "Ankara, İstanbul ve İzmir gibi büyük kentlerde nüfus arttıkça, çevre sorunları da artmaktadır" şeklindeki 26. ifadedir ( $\overline{\mathrm{x}}=4.60)$. En düşük ortalamaya sahip ifade ise "Türkiye'de çevre kirliliği sorunu yoktur." şeklindeki 4. ifadedir $(\overline{\mathrm{x}}=1.42)$.

\section{Araştırmanın İkinci Alt Problemine İlişkin Bulgular}

Öğretmenlerin çevresel tutum ölçeği puanlarının cinsiyete göre T-testi sonuçları Tablo 4 'te verilmiştir.

Tablo 4. Çevresel Tutum Ölçeği Puanlarının cinsiyete göre T-testi sonuçları

\begin{tabular}{lllllll}
\hline Cinsiyet & $\mathbf{N}$ & $\mathbf{X}$ & $\mathbf{S}$ & $\mathbf{S d}$ & $\mathbf{T}$ & $\mathbf{P}$ \\
\hline ÇSF & & & & & & \\
Kadın & 131 & 2.98 & 0.37 & 186 & 1.507 & 0.134 \\
Erkek & 57 & 3.07 & 0.38 & & & \\
ÇYT & & & & & & \\
Kadın & 131 & 3.50 & 0.33 & 186 & 0.879 & 0.380 \\
Erkek & 57 & 3.45 & 0.42 & & & \\
BSB & & & & & & \\
Kadın & 131 & 3.99 & 0.35 & 186 & 2.403 & $.017^{*}$ \\
Erkek & 57 & 3.85 & 0.40 & & & \\
UÇF & & & & & & \\
Kadın & 131 & 3.09 & 0.36 & 186 & 0.151 & 0.151 \\
Erkek & 57 & 3.01 & 0.38 & & & \\
CCTÖ & 131 & 3.47 & 0.24 & 186 & 1.086 & 0.737 \\
(Genel) & 57 & 3.42 & 0.27 & & & \\
\hline P<0.05* & & & & & &
\end{tabular}

Tablo 4' te ilkokul öğretmenlerinin çevresel tutumları incelendiğinde BSB (Bireysel Sorumluluk Bilinci) alt boyutunun cinsiyete göre anlamlı fark gösterdiği tespit edilmiştir $(\mathrm{t}(186)=2.403, \mathrm{p}<.05)$. Kadın öğretmenlerin bireysel sorumluluk bilincine yönelik tutum puanı ortalamaları $(X=3.99)$, erkek öğretmenlere ( $\mathrm{X}=3.85)$ göre daha yüksektir. Anlamlı fark tespit edilen BSF alt boyutu için hesaplanan Cohen d değeri 0.37 'dir. Bu sonuç da kadın ve erkek öğretmenlerin tutum ölçeği ortalama puanları arasındaki farkın .37 standart sapma kadar olduğunu gösterir. Diğer alt faktörler; ÇSF (Çevre Sorunları Farkındalığı), ÇYT (Çözüme Yönelik Tutum) ve UÇF (Ulusal Çevre Farkındalığı)' dır. Bu faktörlerin 
sonuçlarına göre ÇSF $(\mathrm{t}(186)=1.507, \mathrm{p}>.05)$, ÇYT $(\mathrm{t}(186)=0.879, \mathrm{p}>.05)$ ve $\mathrm{UÇF}(\mathrm{t}(186)=0.151, \mathrm{p}>.05)$ alt boyutları da incelenmiş ve anlamlı fark bulunmamıştır.

Analiz sonucunda öğretmenlerin çevreye yönelik genel tutumu ile cinsiyet değişkeni ile arasında anlamlı fark bulunamamıştır $(\mathrm{t}(186)=1.086, \mathrm{p}>.05)$. Cinsiyetin öğretmenlerin çevresel tutumları üzerinde etkisi yoktur sonucuna ulaşılmıştır.

\section{Araştırmanın Üçüncü Alt Problemine İlişkin Bulgular}

Öğretmenlerin çevresel tutum ölçeği puanlarının yaşa göre ANOVA sonuçları Tablo 5’te verilmiştir.

Tablo 5. Çevresel Tutum Ölçeği Puanlarının Yaşa Göre ANOVA Sonuçları

\begin{tabular}{|c|c|c|c|c|c|c|c|}
\hline $\begin{array}{l}\text { Alt } \\
\text { Boyutlar }\end{array}$ & Yaş & $\mathbf{N}$ & $\overline{\mathbf{X}}$ & SS & $\mathbf{F}$ & $\mathbf{P}$ & $\begin{array}{l}\text { Anlaml } \\
\text { Fark }\end{array}$ \\
\hline \multirow[t]{5}{*}{ ÇSF } & $18-25$ yaş & 15 & 2.87 & 0.34 & 0.838 & .502 & \\
\hline & $26-35$ yaş & 65 & 2.99 & 0.38 & & & \\
\hline & $36-45$ yaş & 74 & 3.03 & 0.38 & & & \\
\hline & 46-55 yaş & 26 & 3.01 & 0.34 & & & \\
\hline & 55 yaş üstü & 8 & 3.13 & 0.47 & & & \\
\hline \multirow[t]{5}{*}{ ÇYT } & $18-25$ yaş & 15 & 3.37 & 0.31 & 1.430 & .226 & \\
\hline & $26-35$ yaş & 65 & 3.52 & 0.23 & & & \\
\hline & $36-45$ yaş & 74 & 3.52 & 0.38 & & & \\
\hline & $46-55$ yaş & 26 & 3.41 & 0.38 & & & \\
\hline & 55 yaş üstü & 8 & 3.31 & 0.61 & & & \\
\hline \multirow[t]{5}{*}{ BSB } & $18-25$ yaş & 15 & 3.87 & 0.31 & 1.612 & .173 & \\
\hline & $26-35$ yaş & 65 & 4.02 & 0.37 & & & \\
\hline & $36-45$ yaş & 74 & 3.94 & 0.37 & & & \\
\hline & $46-55$ yaş & 26 & 3.91 & 0.33 & & & \\
\hline & 55 yaş üstü & 8 & 3.71 & 0.60 & & & \\
\hline \multirow[t]{5}{*}{ UÇF } & $18-25$ yaş & 15 & 3.04 & 0.23 & 0.574 & .183 & \\
\hline & $26-35$ yaş & 65 & 3.14 & 0.31 & & & \\
\hline & $36-45$ yaş & 74 & 3.04 & 0.39 & & & \\
\hline & 46-55 yaş & 26 & 2.94 & 0.38 & & & \\
\hline & 55 yaş üstü & 8 & 3.16 & 0.66 & & & \\
\hline \multirow{5}{*}{$\begin{array}{l}\text { ÇTÖ } \\
\text { (Genel) }\end{array}$} & $18-25$ yaş & 15 & 3.35 & 0.20 & 1.431 & .225 & \\
\hline & $26-35$ yaş & 65 & 3.49 & 0.21 & & & \\
\hline & $36-45$ yaş & 74 & 3.46 & 0.25 & & & \\
\hline & $46-55$ yaş & 26 & 3.41 & 0.25 & & & \\
\hline & 55 yaş üstü & 8 & 3.37 & 0.49 & & & \\
\hline
\end{tabular}


Tablo 5'e göre öğretmenlerin ÇSF alt boyutunda yaşa göre anlamı farklılık görülmemektedir, $F(4,183)=0.838, p>.05$. ÇYT alt boyutunda da yaşa göre anlamlı farklılık görülmemektedir, $F(4,183)=$ $1.439, \mathrm{P}>.05$. BSB alt boyutu yaşa göre anlamlı farkl111k göstermemektedir, $\mathrm{F}(4,183)=1.612, \mathrm{p}>.05$. $\mathrm{UÇF}$ alt boyutu da yaşa göre anlamlı farkl11ık göstermemektedir, $F(4,183)=1.574, p>.05$. Analiz sonucunda, çevreye yönelik tutum ile öğretmenlerin yaşları arasında incelenen dört alt boyutta da anlamlı farklılık bulunmamaktadır.

Analiz sonucunda öğretmenlerin çevreye yönelik genel tutumu ile yaş değişkeni ile arasında anlamlı fark bulunmamıştır, $\mathrm{F}(4,183)=1.431, \mathrm{p}>.05$. Yaşın öğretmenlerin çevresel tutumları üzerinde etkisi yoktur sonucuna ulaşılmıştır.

\section{Araştırmanın Dördüncü Alt Problemine İlişkin Bulgular}

Öğretmenlerin çevresel tutum ölçeği puanlarının medeni durumlarına göre T-testi sonuçları Tablo 6' da verilmiştir.

Tablo 6. Öğretmenlerin Çevresel Tutum Ölçeği Puanlarının Medeni Duruma Göre Dağılımı T-Testi Sonuçları

\begin{tabular}{lllllll}
\hline Cinsiyet & N & X & S & Sd & T & P \\
\hline ÇSF & & & & & & \\
Evli & 145 & 3.03 & 0.39 & 186 & 1.676 & .095 \\
Bekar & 43 & 2.92 & 0.31 & & & \\
ÇYT & & & & & & \\
Evli & 145 & 3.48 & 0.37 & 186 & 0.136 & .892 \\
Bekar & 43 & 3.49 & 0.31 & & & \\
BSB & & & & & & \\
Evli & 145 & 3.95 & 0.38 & 186 & 0.055 & .956 \\
Bekar & 43 & 3.94 & 0.35 & & & \\
UÇP & & & & & & \\
Evli & 145 & 3.07 & 0.38 & 186 & 0.023 & .982 \\
Bekar & 43 & 3.06 & 0.32 & & & \\
ÇTÖ & 145 & 3.46 & 0.26 & 186 & 0.767 & .238 \\
(genel) & 43 & 3.43 & 0.20 & & & \\
\hline
\end{tabular}

Tablo 6'ya göre öğretmenlerin çevreye yönelik tutumları medeni durumlarına göre dört alt boyut için de incelenmiştir. ÇSF alt boyutu ile öğretmenlerin medeni durumları anlamlı farklılık göstermemektedir, $\mathrm{t}(186)=1.676, \mathrm{p}>.05$. ÇYT alt boyutu ile öğretmenlerin medeni durumları anlamlı farklılık göstermemektedir, $\mathrm{t}(186)=1.136, \mathrm{p}>.05$. BSB alt boyutu ile öğretmenlerin medeni durumları anlamlı farklılık göstermemektedir, $\mathrm{t}(186)=0.055, \mathrm{p}>.05$. UÇF alt boyutu ile öğretmenlerin medeni durumları anlamlı farklılık göstermemektedir, $t(186)=0.023, p>.05$. incelenen dört alt boyut için de öğretmenlerin medeni durumları arasında anlamlı farklılık görülmemiştir. 
Analiz sonucunda öğretmenlerin çevreye yönelik genel tutumu ile medeni durum değişkeni arasında anlamlı fark bulunmamaktadır $(\mathrm{t}(186)=0.767, \mathrm{p}>.05)$. Medeni durumun öğretmenlerin çevresel tutumları üzerinde etkisi yoktur sonucuna ulaşılmıştır.

\section{Araştırmanın Beşinci Alt Problemine İlişskin Bulgular}

Öğretmenlerin çevresel tutum ölçeği puanlarının kıdeme göre ANOVA sonuçları Tablo 7'de verilmiştir.

Tablo 7. Çevresel Tutum Ölçeği Puanlarının Kıdeme Göre ANOVA Sonuçları

\begin{tabular}{|c|c|c|c|c|c|c|c|}
\hline $\begin{array}{l}\text { Alt } \\
\text { Boyutlar }\end{array}$ & Yaş & $\mathbf{N}$ & $\overline{\mathbf{X}}$ & SS & $\mathbf{F}$ & $\mathbf{P}$ & $\begin{array}{l}\text { Anlamlı } \\
\text { Fark } \\
\end{array}$ \\
\hline \multirow[t]{4}{*}{ ÇSF } & $1-10 \mathrm{y} 1 \mathrm{l}$ & 72 & 2.95 & 0.37 & 1.066 & .365 & \\
\hline & $11-20$ y1l & 68 & 3.03 & 0.36 & & & \\
\hline & $21-29$ y1l & 31 & 3.03 & 0.38 & & & \\
\hline & 30 yll ve üzeri & 17 & 3.05 & 0.44 & & & \\
\hline \multirow[t]{4}{*}{ ÇYT } & $1-10$ y1l & 72 & 3.47 & 0.31 & 1.534 & .207 & \\
\hline & $11-20 \mathrm{y} 1 \mathrm{l}$ & 68 & 3.54 & 0.36 & & & \\
\hline & $21-29$ y1l & 31 & 3.44 & 0.40 & & & \\
\hline & 30 yll ve üzeri & 17 & 3.38 & 0.45 & & & \\
\hline \multirow[t]{4}{*}{ BSB } & $1-10 \mathrm{y} 1 \mathrm{l}$ & 72 & 3.94 & 0.33 & 1.680 & .173 & \\
\hline & $11-20 \mathrm{y} 1 \mathrm{l}$ & 68 & 4.01 & 0.36 & & & \\
\hline & $21-29$ y1l & 31 & 3.88 & 0.42 & & & \\
\hline & 30 yil ve üzeri & 17 & 3.84 & 0.49 & & & \\
\hline \multirow[t]{4}{*}{ UÇF } & $1-10$ y1l & 72 & 3.07 & 0.30 & .590 & .622 & \\
\hline & $11-20$ y1l & 68 & 3.12 & 0.38 & & & \\
\hline & 21-29 y1l & 31 & 3.40 & 0.37 & & & \\
\hline & 30 yll ve üzeri & 17 & 3.07 & 0.51 & & & \\
\hline \multirow{4}{*}{$\begin{array}{l}\text { ÇTÖ } \\
\text { (genel) }\end{array}$} & $1-10$ yil & 72 & 3.44 & 0.22 & 1.401 & .171 & \\
\hline & $11-20 \mathrm{y} 1 \mathrm{l}$ & 68 & 3.50 & 0.22 & & & \\
\hline & $21-29$ y1l & 31 & 3.41 & 0.29 & & & \\
\hline & 30 yıl ve üzeri & 17 & 3.41 & 0.37 & & & \\
\hline
\end{tabular}

Tablo 7'ye göre öğretmenlerin ÇSF alt boyutunda mesleki kıdeme göre anlamı farklılık görülmemektedir. $\mathrm{F}(3,184)=0.707, \mathrm{p}>.05$. ÇYT alt boyutunda da kıdeme göre anlamlı farklılık görülmemektedir, $\mathrm{F}(3,184)=1.285, \mathrm{P}>.05$. $\mathrm{BSB}$ alt boyutu k1deme göre anlamlı farkl111k göstermemektedir, $\mathrm{F}(3,184)=1.372, \mathrm{p}>.05$. UÇF alt boyutu da k1deme göre anlamlı farklılık 
göstermemektedir. $F(3,184)=1.571, p>.05$. Analiz sonucunda, çevreye yönelik tutum ile öğretmenlerin mesleki kıdemleri arasında incelenen dört alt boyutta da anlamlı farklılık bulunmamaktadır.

Analiz sonucunda öğretmenlerin çevreye yönelik genel tutumu ile mesleki kıdem değişkeni arasında anlamlı fark bulunmamaktadır $(\mathrm{F}(3,184)=1.401, \mathrm{p}>.05)$. Mesleki kıdemin öğretmenlerin çevresel tutumları üzerinde etkisi yoktur sonucuna ulaşılmıştır.

\section{Araştırmanın Altıncı Alt Problemine İlişkin Bulgular}

Öğretmenlerin çevresel tutum ölçeği puanlarının aylık gelire göre ANOVA testi sonuçları Tablo 8' de verilmiştir.

Tablo 8. Çevresel Tutum Ölçeği Puanlarının Aylık Gelire Göre ANOVA Sonuçları

\begin{tabular}{|c|c|c|c|c|c|c|c|}
\hline $\begin{array}{l}\text { Alt } \\
\text { Boyutlar }\end{array}$ & Yaş & $\mathbf{N}$ & $\overline{\mathbf{X}}$ & SS & $\mathbf{F}$ & $\mathbf{P}$ & $\begin{array}{l}\text { Anlaml } \\
\text { Fark }\end{array}$ \\
\hline \multirow[t]{4}{*}{ ÇSF } & $1000-2499 \mathrm{TL}$ & 12 & 3.28 & 0.30 & 1.047 & .373 & \\
\hline & 2500-3499 TL & 5 & 2.93 & 0.56 & & & \\
\hline & 3500-4499 TL & 80 & 3.01 & 0.35 & & & \\
\hline & 4500 TL üzeri & 91 & 3.03 & 0.38 & & & \\
\hline \multirow[t]{4}{*}{ ÇYT } & 1000-2499 TL & 12 & 3.28 & 0.30 & 1.922 & .128 & \\
\hline & 2500-3499 TL & 5 & 3.37 & 0.14 & & & \\
\hline & 3500-4499 TL & 80 & 3.57 & 0.35 & & & \\
\hline & 4500 TL üzeri & 91 & 3.47 & 0.38 & & & \\
\hline \multirow[t]{4}{*}{ BSB } & 1000-2499 TL & 12 & 3.83 & 0.28 & 1.122 & .342 & \\
\hline & 2500-3499 TL & 5 & 3.98 & 0.27 & & & \\
\hline & 3500-4499 TL & 80 & 4.00 & 0.40 & & & \\
\hline & 4500 TL üzeri & 91 & 3.91 & 0.37 & & & \\
\hline \multirow[t]{4}{*}{ UÇF } & 1000-2499 TL & 12 & 2.88 & 0.26 & 1.058 & .368 & \\
\hline & 2500-3499 TL & 5 & 3.10 & 0.32 & & & \\
\hline & $3500-4499 \mathrm{TL}$ & 80 & 3.07 & 0.38 & & & \\
\hline & 4500 TL üzeri & 91 & 3.09 & 0.37 & & & \\
\hline \multirow{4}{*}{$\begin{array}{l}\text { ÇTÖ } \\
\text { (Genel) }\end{array}$} & 1000-2499 TL & 12 & 3.30 & 0.18 & 2.084 & .198 & \\
\hline & 2500-3499 TL & 5 & 3.42 & 0.07 & & & \\
\hline & 3500-4499 TL & 80 & 3.49 & 0.26 & & & \\
\hline & 4500 TL üzeri & 91 & 3.45 & 0.25 & & & \\
\hline
\end{tabular}

Tablo 8'e göre öğretmenlerin çevre sorularının farkındalığı alt boyutu ile aylık gelir arasında anlamlı farklı1ık bulunmamıştır, $F(3,184)=1.047, p>$.05. Çözüme yönelik tutum alt boyutu ile aylık gelir arasında anlamlı farklılık bulunmamaktadır, $\mathrm{F}(3,184)=1.922, \mathrm{p}>.05$. Bireysel sorumluluklarının bilinci alt boyutu ile aylık gelir arasında anlamlı farklılık bulunmamaktadır, $F(3,184)=1.122, p>.05$. Ulusal 
çevre farkındalığı alt boyutu ile aylık gelir arasında anlamlı farklılık bulunmamaktadır, $\mathrm{F}(3,184)=1.058$, p>.05. Öğretmenlerin çevreye yönelik tutumları ile aylık gelirleri dört alt boyut için de anlamlı farklılık göstermemektedir.

Analiz sonucunda öğretmenlerin çevreye yönelik genel tutumu ile aylık gelir değiş̧keni arasında anlamlı fark bulunmamaktadır, $\mathrm{F}(3,184)=2.084, \mathrm{p}>.05)$. Aylık gelirin öğretmenlerin çevresel tutumları üzerinde etkisi yoktur sonucuna ulaşılmıştır.

\section{Araştırmanın Yedinci Alt Problemine İlişkin Bulgular}

Öğretmenlerin çevresel tutum ölçeği puanlarının branşa göre ANOVA testi sonuçları Tablo 9' da verilmiştir.

Tablo 9. Çevresel Tutum Ölçeği Puanlarının Branşa Göre ANOVA Sonuçları

\begin{tabular}{|c|c|c|c|c|c|c|c|}
\hline $\begin{array}{l}\text { Alt } \\
\text { Boyutlar }\end{array}$ & Yaş & $\mathbf{N}$ & $\overline{\mathbf{X}}$ & SS & $\mathbf{F}$ & $\mathbf{p}$ & $\begin{array}{l}\text { Anlamlı } \\
\text { Fark }\end{array}$ \\
\hline \multirow[t]{5}{*}{ ÇSF } & Sınıf Öğretmeni & 129 & 2.99 & 0.38 & 0.838 & .502 & \\
\hline & İngilizce & 13 & 3.04 & 0.39 & & & \\
\hline & Türkçe & 11 & 3.00 & 0.28 & & & \\
\hline & Okul öncesi & 9 & 3.22 & 0.54 & & & \\
\hline & Diğer & 26 & 2.99 & 0.29 & & & \\
\hline \multirow[t]{5}{*}{ ÇYT } & Sınıf Öğretmeni & 129 & 3.46 & 0.31 & 1.430 & .226 & \\
\hline & İngilizce & 13 & 3.50 & 0.23 & & & \\
\hline & Türkçe & 11 & 3.61 & 0.38 & & & \\
\hline & Okul öncesi & 9 & 3.62 & 0.38 & & & \\
\hline & Diğer & 26 & 3.49 & 0.61 & & & \\
\hline \multirow[t]{5}{*}{ BSB } & Sınıf Öğretmeni & 129 & 3.94 & 0.31 & 1.612 & .173 & \\
\hline & İngilizce & 13 & 3.98 & 0.37 & & & \\
\hline & Türkçe & 11 & 4.02 & 0.37 & & & \\
\hline & Okul öncesi & 9 & 3.86 & 0.33 & & & \\
\hline & Diğer & 26 & 3.97 & 0.60 & & & \\
\hline \multirow[t]{5}{*}{ UÇF } & Sınıf Öğretmeni & 129 & 3.04 & 0.23 & 0.574 & .183 & \\
\hline & İngilizce & 13 & 3.01 & 0.31 & & & \\
\hline & Türkçe & 11 & 3.27 & 0.39 & & & \\
\hline & Okul öncesi & 9 & 3.22 & 0.38 & & & \\
\hline & Diğer & 26 & 2.08 & 0.66 & & & \\
\hline \multirow{5}{*}{$\begin{array}{l}\text { ÇTÖ } \\
\text { (Genel) }\end{array}$} & Sınıf Öğretmeni & 129 & 3.44 & 0.26 & 0.711 & .159 & \\
\hline & İngilizce & 13 & 3.47 & 0.16 & & & \\
\hline & Türkçe & 11 & 3.53 & 0.20 & & & \\
\hline & Okul öncesi & 9 & 3.55 & 0.38 & & & \\
\hline & Diğer & 26 & 3.46 & 0.20 & & & \\
\hline
\end{tabular}


Tablo 9'a göre öğretmenlerin ÇSF alt boyutunda branşa göre anlamı farkl1lık görülmemektedir. $\mathrm{F}(4,183)=0.807, \mathrm{p}>.05$. ÇYT alt boyutunda da branşa göre anlamlı farklılık görülmemektedir, $\mathrm{F}(4,183)$ $=0.849, \mathrm{P}>.05$. BSB alt boyutu branşa göre anlamlı farkl1l1k göstermemektedir, $\mathrm{F}(4,183)=0.310, \mathrm{p}>.05$. UÇF alt boyutu da branşa göre anlamlı farkl11ık göstermemektedir. $F(4,183)=1.413, p>.05$. Analiz sonucunda, çevreye yönelik tutum ile öğretmenlerin branşları arasında incelenen dört alt boyutta da anlamlı farklılık bulunmamaktadır.

Analiz sonucunda öğretmenlerin çevreye yönelik genel tutumu ile branş değişkeni arasında anlamlı farklılık bulunmamaktadır, $(F(3,184)=0.711, p>.05)$. Farklı branşların öğretmenlerin çevresel tutumları üzerinde etkisi yoktur sonucuna ulaşı1mıştır.

\section{TARTIŞMA VE SONUÇ}

Bu araştırmada Düzce ilindeki İlkokul öğretmenlerinin çevreye yönelik tutumlarının cinsiyet, yaş, aylık gelir, medeni durum, mesleki kıdem ve branşları açısından değişkenlik gösterip göstermediği incelenmiş olup, değişkenlerin öğretmenlerin tutumları üzerindeki etkisi ve ölçeğin faktörleriyle olan ilişkisi ortaya konmuştur.

Çevresel tutumlar 4 alt boyutta değerlendirilmiştir. Bu alt boyutlar çevre sorunlarının farkındalığı, çözüme yönelik tutum, bireysel sorumluluk bilinci ve ulusal çevre farkındalığını ölçmeye yöneliktir. Yapılan analizler önceden belirlenmiş olan 6 farklı değişken için 4 alt boyutta da ayrı ayrı incelenmiştir. Bu değişkenler cinsiyet, yaş, mesleki kıdem, branş, medeni durum ve aylık gelir olarak belirlenmiştir.

Çevre sorunlarının farkında olma alt problemi için verilen cevaplara bakıldığında en düşük ortalamaya sahip ifadenin "Denizlerin içerisinde yüzülemeyecek kadar kirli hale gelmesi doğal bir olaydır" olduğu görülmektedir. Bunun sebebi öğretmenlerin denizlerdeki çevre kirliliğinin insanlardan kaynaklı bir durum olduğuna inanmaları olabilir. Ayrıca insanlar tarafından denize atılan atık maddelerin ve sanayi atıklarının da deniz suyunu kirlettiği düşünülürse deniz içerisindeki canlı hayatının da tehlikede olduğu söylenebilir. Yine çevre sorunlarının farkında olma alt problemi için en yüksek ortalamaya sahip ifadenin “Çevre kirliliği insan sağhlğını olumsuz yönde etkiler” olduğu görülmektedir. Bunun sebebi zamanla çevre kirliliğinden kaynaklı solunum rahatsızlıklarının artması veya temiz suya ulaşımın zorlaşması gibi nedenlerden çevre kirliliğinin etkilerinin insanlar tarafından gün geçtikçe daha da hissedilmesi olduğu söylenebilir.

Çözüme yönelik tutum alt problemi için verilen cevaplara bakıldığında en düşük ortalamaya sahip ifadenin "Çevre kirliliğinin nüfus artışı ile hiçbir ilgisi yoktur" olduğu görülmektedir. Bunun sebebi ülkelerin gelişmişlik düzeyinin artmasıyla, illerdeki nüfusun zamanla yükselmesi veya büyük şehirlerde çalışma olanaklarının fazlalığından dolayı insanların büyük şehirlere yerleşmeleriyle çevre kirliliğinin etkilerini gün geçtikçe daha da fark ediyor olmaları olabilir. Yine bu durumun sebebi öğretmenlerin büyük şehirlerde çalışmış olması veya büyük şehirlerde yaşanan çevre problemlerinden haberdar olması 
da olabilir. Çözüme yönelik tutum için cevap verilen en yüksek ortalamaya sahip ifadenin de "İnsanoğlu yaşamını sürdürebilmek için doğa ile uyum içinde yaşamak zorundadır” olduğu görülmektedir. Bunun sebebi de yine insanların çevreye verdiği zararın sonuçlarını artık daha fazla hissetmesi olduğu söylenebilir. İnsanların çevreyle daima uyum içerisinde yaşaması, çevreye karşı duyarlı ve koruyucu tavırlar takınması gerekmektedir.

Bireysel sorumluluklarının bilincinde olma alt problemi için verilen cevaplar arasında en düşük ortalamaya sahip olan cevabın "Tüketim alışkanlıklarımızın doğal kaynakların tükenmesi ile ilgisi yoktur" olduğu görülmektedir. Bunun sebebi doğal kaynaklara verilen zararın insan hayatı için oldukça büyük öneme sahip olması ve doğal kaynakların tükenmesi sonucunda insan hayatının da tehlikeye girdiği gerçeği olabilir. Son zamanlarda su kaynaklarının azalması, suya olan ihtiyacın daha da artması ve insanların suyu bilinçsizce tüketmesinden kaynaklı yaşadıkları problemler de olabilir. Bireysel sorumluklarının bilincinde olma alt problemi için verilen en yüksek ortalamaya sahip cevabın ise " $\mathrm{Su}$ ve elektrik kullanırken tasarruflu davranmak doğal kaynakların sürdürülebilir kullanımı açısından önemlidir" ifadesi olduğu görülmektedir. Bunun sebebi yine öğretmenlerin su ve elektrik kullanımlarında tasarrufun canlı yaşamı için öneminin farkında olması olabilir. Kaynakların sürdürülebilir kullanımı gelecek nesiller için oldukça önemlidir.

Ulusal çevre problemlerinin farkındalığı alt problemine ilişkin verilen cevaplar arasında en düşük ortalamaya sahip olan cevabın "Türkiye’ de çevre kirliliği sorunu yoktur" ifadesi olduğu görülmektedir. Bunun sebebi öğretmenlerin Türkiye'de çevre sorunlarının var olduğu düşünmeleri ve ülkemiz için sorun teşkil ettiğini düşünmeleri olabilir. Ülkemizde çevre kirliliği sorunlarına ve çevreyi korumaya yönelik yapılan projeler, çalışmalar vb. etkinlikler düşünüldügünde hala çevre sorunlarının mevcut olduğunu söyleyebiliriz. Ulusal çevre problemlerinin farkındalığı alt problemi için verilen en yüksek ortalamaya sahip cevabın ise “ Ankara, İstanbul, İzmir gibi büyük kentlerde nüfus arttıç̧, çevre sorunları da artmaktadır" olduğu görülmektedir. Bu cevabın sebebi öğretmenlerin daha önce bu büyük şehirlerde çalışma durumları veya orada yaşayan yakınlarından duydukları problemler olabilir. Yine çözüme yönelik tutum alt problemlerinde en düşük ortalamaya sahip olarak verilen cevap olan çevre kirliliğinin nüfusla ilgisi olmadığı ifadesi ile de bu durum ilişkilendirilebilir. Nüfus kaynaklı çevre problemlerine ilişkin verilen cevaplardan yola çıkılarak öğretmenlerin, çevreyi kirleten unsurlardan biri olan nüfus artışının çevre için önemli bir problem olduğunu düşündükleri sonucuna varılabilir.

Çalışmada ilkokul öğretmenlerinin çevresel tutum ölçeği faktörleri çeşitli değişkenler bakımından değerlendirilmiş ve cinsiyet değişkeni için 4 alt boyutta elde edilen sonuçlara göre; bireysel sorumluluk bilinci alt boyutunda kadın ve erkek öğretmenler arasında farklılık tespit edilmiştir. Kadın öğretmenlerin erkek öğretmenlere göre daha fazla bireysel sorumluluklarının bilincinde olduğu bulgusuna ulaşılmıştır. Diğer alt boyutların da cinsiyet değişkeniyle arasında herhangi bir ilişkiye rastlanmamıştır. Büyükkaynak ve Aslan (2019)' un yaptıkları çalışma sonucunda kadın ve erkek öğretmenler arasında 
farklılığa rastlamış ve sonuçlara göre kadın adayların erkek adaylara göre daha olumlu tutuma sahip olduğu, bunun nedenininse toplumsal olabileceğini veya sosyal grupların da farklı olmasından kaynaklanabileceğini düşünmüşlerdir. Çevre eğitiminin başarıya ulaşabilmesi için erkek öğretmen adaylarına yönelik olumlu tutum geliştirecek ve davranış değişikliği oluşturacak planlamalar yapılmalıdır. Çimen ve Benzer (2019) fen bilgisi ve sınıf öğretmen adaylarının sürdürülebilir çevreye yönelik tutumlarını incelediği çalışmasında kadın ve erkek adaylar arasında farklılık bulmuş ve kız öğrencilerin erkek öğrencilere göre var oluşları itibariyle her zaman daha duyarlı ve hassas olmalarından kaynaklı olabileceğini ortaya koymuştur. Erbasan ve Erkol (2020) yaptıkları çalışmada sınıf öğretmenlerinin çevreye yönelik bilgi, tutum ve davranış puanlarının cinsiyete göre değişmediğini ortaya koymuşlardır. Bunun sebebini de günümüzde toplumsal cinsiyet rolleri arasındaki farkın gittikçe azalması olarak açıklamışlardır. Yapılan araştırmaların çoğunda, çevreye yönelik kadın ve erkek öğretmenlerin bireysel sorumluluklarının karşılaştırılması yapıldığında, kadın öğretmenlerin erkek öğretmenlere göre daha bilinçli olduğu sonucuna ulaşılmıştır.

Öğretmenlerin çevresel tutumlarının olumlu yönde olması, ülkemizin ve dünyanın geleceğini belirlemeye yönelik atılacak çok önemli bir adımdır. Öğretmenler geleceğimizin şekillenmesinde yardımcı olan en önemli karakterlerdendir. Aileden sonra davranış ve tutumlarıyla çocuklara örnek olacak, onların tavır ve tutumlarını en çok etkileyen öğretmenler olacaktır. Öyleyse öğretmenlerin çevreye yönelik tutumları çevre bilincinin kazandırılmasında oldukça önemlidir. Küçük yaşlarda kazandırılacak alışkanlıklar ve pozitif davranışlar çocukların ileride çevreye karşı daha duyarlı olmalarını sağlayacaktır.

Çevreye yönelik tutum sürdürülebilir olmalıdır. Sürdürülebilirlik sonraki nesillerinde yaşam kalitelerini tehlikeye sokmadan onların hayatını güvence altına alarak sağlanabilir. Çevreye duyarlı toplumlar tüm dünyanın kaderini değiştirebilecek niteliktedir. Gelecekteki zararları önlemeye yönelik yapılacak çalışmalar toplumların gelişmişlik düzeyini de arttıracaktır. Gelişmiş ülkeler sürdürülebilirliği diğer ülkelere göre daha iyi başarmış ülkelerdir. Sürdürülebilirlik hedeflerinin içerisine çevrenin korunması da önemli ölçüde yer almaktadır. Suların temiz tutulması, temiz hava sahasının sağlanması vb. hedeflerle insanların sağlıklı çevrede yaşamasının sağlanması amaçlanmıştır. Çevreyi korumayı başarmış nesiller yetiştirmek tüm dünyanın hedefi olmalıdır. Yine sürdürülebilir kalkınmanın hedefleri içerisinde eğitimin önemi de yer almaktadır. İnsanların her konuda bilgi sahibi olması ve çevreyi korumaya yönelik nasıl davranacağı konusunda eğitimin rolü oldukça önemlidir. Bu eğitimi insanlara verecek olan öğretmenlerin de oldukça dikkatli olması gerekmektedir.

Küçük yaşlarda kazandırılması gereken istendik davranışlar aileler ve ilkokul öğretmenleri sayesinde olmaktadır. İlkokul öğretmenleri çevre konusunda duyarlı ve bilinçli olmalıdır. Ayrıca çevreye yönelik tutum yalnızca kadınlar ya da erkekler için ayrı tutulması gereken bir durum değildir. Her iki tarafında olumlu tavır ve tutum içerisinde olmaları gerekmektedir. Bu çalışmada ilkokul 
öğretmenlerinin çevreye yönelik tutumlarının değerlendirilmesi sonucunda, cinsiyet rolüne bağlı olarak kadın ve erkek öğretmenler arasında farklılıklar olduğu saptanmıştır. Bu durumdan yola çıkılarak erkek öğretmenlerin kadın öğretmenlere göre çevreye daha duyarlı olması gerektiği sonucuna ulaşılmaktadır. Çevreye yönelik verilecek eğitimlerle bu farkl1lık olumlu yönde giderilebilir.

Çalışma sonucunda çevreye yönelik tutumun sadece bireysel sorumlulukların bilincinde olma alt probleminde, cinsiyet değişkeni üzerinde anlamlı fark olduğu görülmüştür. Bunun haricinde incelenen diğer değişkenler olan; yaş, mesleki kıdem, medeni durum, aylık gelir ve branş üzerine yapılan analizler sonucunda, çevreye yönelik tutumun dört alt probleminde de anlamlı farklılığa rastlanmamıştır.

Ayrıca çevreye yönelik tutum ölçeğinin tüm değişkenler açısından genel değerlendirilmesi de yapılmış olup, belirlenmiş olan altı değişken için de anlamlı farklılığa rastlanmamıştır. Çevresel tutum ile cinsiyet, yaş, mesleki kıdem, medeni durum, aylık gelir ve branş arasında bir ilişki bulunamamıştır.

\section{Öneriler}

\section{Uygulayıcılara Yönelik Öneriler}

- Öğretmenlerin mezun oldukları yükseköğretim bölümlerine, çevreye yönelik olumlu tavır ve tutum geliştirecek olan dersler eklenebilir. Eklenilen dersler zorunlu hale getirilip, kredisi arttırılarak ve uygulamalı eğitimlerle de desteklenerek bu konunun önemi vurgulanabilir.

- Öğretmenler için mesleğe başladıkları yıldan itibaren yılda en az bir kez olmak üzere çevre konusunda eğitimler verilebilir. Çevre konusunda duyarlılık her yıl bu şekilde arttırılarak, konunun öneminin devamlılı̆g bu şekilde sağlanabilir.

\section{Araştırmacılara Yönelik Öneriler}

- $\mathrm{Bu}$ araştırma evren ve örneklem sayısı daha da arttırılarak Türkiye genelinde bütün ilkokul öğretmenlerine yapılabilir.

- Araştırmada kullanılan değişkenlerin yanı sıra bu alanda diğer faktörleri ele alan başka değişkenler de eklenerek çalışma alanı daha da genişletilebilir.

- Araştırma yalnızca Düzce ilinde yapılmış olup, Düzce ilinin yanı sıra başka illerde de uygulanıp sonuçlar benzerlik ve farklı1ık açısından karşılaştırılabilir.

- Araştırma çevreye yönelik tutum ölçeğinin yanı sıra davranış ve psikolojiyi içeren çeşitli ölçeklerle birlikte kullanılarak, çevreye yönelik tutum başka bilim alanlarıyla ilişkilendirilip kapsamı genişletilebilir.

- Çevreye yönelik tutumda cinsiyet açısından bulunan anlamlı farklılık Türkiye genelinde farklı illerdeki kadın ve erkek öğretmenlere uygulanıp sonuçların karşılaştırılması yapılabilir. 


\section{KAYNAKÇA}

Alım, M. (2006). Avrupa Birliği üyelik sürecinde Türkiye'de çevre ve ilköğretimde çevre eğitimi. Kastamonu Ĕ̈itim Dergisi, 14(2), 599-616.

Asan, K. (2015). Araştırma Evreni ve Örneklemi (Yayınlanmamış yüksek lisans tezi). Dumlupınar Üniversitesi, Sosyal Bilimler Enstitüsü, Kütahya.

Baykal, H, Baykal, T. (2014). Küreselleşen Dünya'da çevre sorunları. Mustafa Kemal Üniversitesi Sosyal Bilimler Enstitüsü Dergisi, 5(9), 1-17.

Büyükkaynak, E. Aslan, O. (2019). Matematik ve fen bilimleri öğretmen adaylarının çevreye yönelik tutumlar1. Journal of International Social Research, 12(63), 797-807.

Costanza, R. (1991). Ecological Economics: The Science and Management of Sustainability. New York: Colombia University Press.

Çabuk, B, \& Karacaolu Ö. C. (2003). Üniversiteli öğrencilerinin çevre duyarlılıklarının incelenmesi. Ankara University Journal of Faculty of Educational Sciences (JFES), 36(1), 189-198.

Çelikkıran, A. (1995). İnsan, çevre, eğitim. Kuram ve Uygulamada Eğitim Yönetimi, 4(4), 569-572.

Çimen, H, Benzer, S. (2019). Fen bilgisi ve sınıf öğretmen adaylarının sürdürülebilir çevreye yönelik tutumlarının incelenmesi. İnsan ve İnsan, 6 (21), 525-542.

Erbasan, Ö, Erkol, M. (2020). Sınıf öğretmenlerinin çevreye yönelik bilgi, tutum ve davranış düzeylerinin incelenmesi. OPUS Uluslararası Toplum Araştırmaları Dergisi, 15 (24), 2443-2471.

Jickling, B. Spork, H. (1998). Education for the Environment: A critique. Environmental Education Research, 4(3), 309-327.

Kahyaoğlu, M, Özgen, N. (2012). Öğretmen adaylarının çevre sorunlarına yönelik tutumlarının çeşitli değişkenler açısından incelenmesi. Kuramsal Eğitim Bilimleri Dergisi, 5(2), 171-185.

Karakülah, Ü.H. (2006). Basit Rastgele Örnekleme Yönteminde Oransal Tahmin Ediciler (Yayınlanmış yüksek lisans tezi). Hacettepe Üniversitesi, Fen Bilimleri Enstitüsü, Ankara.

Kaypak, Ş. (2013). Çevre Sorunlarının Çözümünde Küresel Çevre Politikaları. Muğla Üniversitesi Sosyal Bilimler Enstitüsü Dergisi, 31, 17-34.

Keleş, Ö, Uzun, N, Uzun, F. (2010). Öğretmen adaylarının çevre bilinci, çevresel tutum, düşünce ve davranışlarının doğa eğitimi projesine bağlı değişimi ve kalıcılığının değerlendirilmesi. Elektronik Sosyal Bilimler Dergisi, 9(32), 384-401.

Özen, Y, Gül, A. (2010). Sosyal ve Eğitim Bilimleri Araştırmalarında Evren-Örneklem Sorunu. Atatürk Üniversitesi Kazım Karabekir Ĕ̈itim Fakültesi Dergisi, 15, 394-422.

Tuncer, G. Sungur, S. Tekkaya, C. Ertepinar, H. (2004). Environmental Attitudes of the 6th Grade Students From rural and Urban Areas: A Case Study for Ankara, H.U. Journal of Education, 26, 167-179.

Tuncer, G., Ertepinar, H., Tekkaya, C., \& Sungur, S. (2005). Environmental attitudes of young people in Turkey: Effects of school type and gender. Environmental Education Research, 11(2) ,215-233.

Türküm, A. S. (1998). Çağdaş toplumda çevre sorunları ve çevre bilinci, Anadolu Üniversitesi, Açık Öğretim Fakültesi, Ünite 10, 165-182. 